\title{
Senile amyloidosis: a protean manifestation of the aging process
}

\author{
GG CORNWELL III AND P WESTERMARK \\ From the Department of Medicine, Dartmouth Medical School, Hanover, NH 03755, USA and the \\ Department of Pathology, University of Uppsala, Uppsala, Sweden
}

SUMMARY Senile amyloidosis represents a group of diseases which, while sharing features common to other forms of amyloidosis, are unique and differ from one another in their morphology, biochemical behaviour, protein components, and organ distribution. Although the exact prevalence of various forms of this group of amyloidosis is not yet known, it appears that some forms are extremely common in elderly patients and in many patients may have no clinical significance.

Senile amyloidosis has often been viewed as an uncommon disorder which differs from other forms of amyloid only with respect to patient age and organ distribution. In recent years, it has become increasingly evident that amyloidosis represents a family of diseases, each member of which may be characterised by unique amyloid fibril proteins, and that the socalled senile amyloidoses are rather distinct members of this family. It is now clear that amyloidosis associated with aging is very common and, although it shares histochemical and morphological features with other forms of amyloidosis, it possesses unique structural, biochemical, and immunological characteristics. Moreover, there is evidence that amyloid deposits present in heart, brain, pancreas, and other tissues of elderly patients may be distinguished from one another on the basis of unique fibrillar appearance and structure, biochemical properties, and protein components. This review summarises recent knowledge regarding the unique characteristics and apparent clinical significance of age-related amyloidosis associated with cardiovascular, pancreatic, and cerebrovascular tissues.

\section{Senile amyloid of the heart}

The frequency of amyloid deposition in the hearts of elderly patients and its significance have been studied by a number of investigators over the past 10-20 years. ${ }^{1=11}$ Since antibody specific for this type of amyloid has not been available until recently, all of these studies have been based on histochemical staining, and variations in the results have been related to the patient population studied and to the

Received for publication 8 April 1980 histochemical criteria used. The published prevalence in patients over 70 years of age has varied from $2 \%^{3}$ to greater than $80 \%{ }^{9}$ In the former series, methyl-violet staining of heart sections was carried out only in those tissues which appeared to contain amyloid by initial screening by haematoxylin and eosin; in the latter study, thioflavine-S was used as an indicator of amyloid deposition, a method found by some investigators to lack specificity for amyloid fibrils. ${ }^{812}$ Several recent postmortem studies using Congo red stain alone ${ }^{10}$ or a combination of Congo red, crystal violet, thioflavine-T, and sulphonated alcian-blue staining ${ }^{11}$ of elderly patients have shown

\begin{tabular}{|c|c|}
\hline \multicolumn{2}{|l|}{ Abbreviations* } \\
\hline SCA & $\begin{array}{l}\text { senile cardiac amyloidosis } \\
\text { (generalised) }\end{array}$ \\
\hline $\operatorname{ASc}_{\mathbf{I}}\left(\mathrm{AscA}_{\mathbf{S C}}\right)$ & $\begin{array}{l}\text { amyloid fibril protein from senile } \\
\text { cardiac amyloid }\end{array}$ \\
\hline IAA & $\begin{array}{l}\text { isolated atrial amyloidosis } \\
\text { (localised) }\end{array}$ \\
\hline AA & amyloid fibril protein $\mathbf{A}$ \\
\hline SAA & serum precursor of protein A \\
\hline $\mathrm{AL}_{\lambda}, \mathrm{AL}_{\kappa}\left(\mathrm{A}_{\lambda}, \mathrm{A}_{\kappa}\right)$ & $\begin{array}{l}\text { immunoglobulin light chain } \\
\text { amyloid fibril proteins of the } \lambda \\
\text { or } \kappa \text { types }\end{array}$ \\
\hline MCT & $\begin{array}{l}\text { medullary carcinoma of the } \\
\text { thyroid }\end{array}$ \\
\hline $\mathrm{AE}_{\mathrm{t}}\left(\mathrm{A}_{\mathrm{M}} \mathrm{CT}\right)$ & $\begin{array}{l}\text { amyloid fibril protein from } \\
\text { medullary carcinoma of the } \\
\text { thyroid }\end{array}$ \\
\hline AP & $\begin{array}{l}\text { serum P-component associated } \\
\text { with amyloidosis. }\end{array}$ \\
\hline
\end{tabular}

*Nomenclature accepted at the Third International Symposium on Amyloidosis, Povoa de Varzim, Portugal, September 1979. Abbreviations in parentheses are those most commonly used in previous publications. 
that approximately $50 \%$ of patients over the age of 60 years have senile cardiac amyloidosis. These and other studies have led to the following general conclusions regarding this type of amyloidosis:

1 Amyloid deposits in the heart are a common occurrence in elderly patients.

2 The prevalence increases with each decade above the age of 60 .

3 The earliest findings are generally manifest as small deposits on the subendocardial surface of the atrium, the left being more common than the right.

4 With increasing age, there is increasing likelihood of involvement of the ventricles (in addition to atria), with an apparent gradual progression from small ventricular foci to larger foci and eventually to diffuse ventricular infiltration.

5 The involvement of extracardiac tissues is rare in cardiac amyloidosis limited to the atria but increases significantly when moderately large foci or diffuse involvement of the ventricles are present. In such patients, however, the extracardiac deposition tends to be limited to the aorta, pulmonary vessels, and pulmonary alveolar septa, with occasional foci in small and medium-sized vessels of other tissues. Despite the fact that the brain and the pancreas are frequently found to contain amyloid in elderly patients, there does not appear to be a close correlation between involvement of the heart and these other organs.

Although the above observations have led to the assumption that isolated atrial amyloidosis (IAA) represents an early stage of generalised (atrial and ventricular) senile cardiac amyloidosis (SCA), recent evidence by Westermark et al..$^{13}$ suggests that IAA is a distinct form of senile amyloid. Evidence for this conclusion will be discussed below.

\section{THE INFLUENCE OF SENILE AMYLOID ON}

CARDIAC FUNCTION

The functional effects of cardiac amyloid in aged patients have been assessed by a number of investigators, and most conclude that clinically significant cardiac disability is rare. The literature has varied regarding the prevalence of heart failure, atrial fibrillation, cardiomegaly, and digitalis sensitivity. Although no correlation has been found between small atrial deposits and clinical signs or symptoms, some authors have concluded that ventricular involvement is commonly associated with changes in cardiac function. Wright and Calkins ${ }^{10}$ found that generalised senile amyloid rarely leads to cardiomegaly and that congestive heart failure is not more prevalent than in an age-matched population. Hodkinson and Pomerance ${ }^{11}$ also failed to find any correlation between the degree of cardiac involvement by senile amyloid and heart weight, ECG changes, pathological evidence of myocardial ischaemia, or digitalis sensitivity. These investigators did conclude, however, that the incidence of heart failure was significantly higher in the group of patients above age 60 with senile amyloid deposits $(53.8 \%)$ than in the group without $(36.5 \%, \mathrm{P}<$ $0.025)$. They also found a high correlation $(P<0.001)$ between atrial fibrillation and cardiac involvement by senile amyloid (no involvement $16 \%$, atria only $27 \%$, atria and ventricles $40 \%$ ). Since $32.3 \%$ of the patients with cardiac amyloidosis in their series had evidence of ventricular involvement, the clinical significance of this disease in elderly patients may be of greater magnitude than was previously suspected. At the present time, there is no definitive antemortem technique, short of myocardial biopsy, that will establish the diagnosis.

\section{BIOCHEMICAL CHARACTERISTICS}

Unique biochemical properties of amyloid fibrils associated with generalised senile cardiac amyloidosis (SCA) have recently been described. ${ }^{14}$ Whereas fibrils present in primary and secondary amyloid deposits are readily extracted in water, ${ }^{15}$ amyloid fibrils associated with SCA are considerably less soluble in water and are found in the top of the residual heart tissue pellet after extraction in water. In addition, a unique amyloid fibril protein. $\mathrm{ASc}_{\mathrm{I}}$ (previously designated ASCA), has been found in association with SCA. ${ }^{14}$ This protein was isolated from the ventricles of two patients with senile cardiac amyloidosis and fractionated by chromotography on Sepharose 6B. It was found to have a molecular weight of approximately 6000 daltons and to be different in amino acid composition from protein AA, the predominant small molesular weight protein present in secondary amyloid deposits. An antiserum raised in rabbits to a degraded preparation of isolated fibrils from one patient reacted by immunodiffusion with similar preparations from four other patients with advanced SCA but not with material similarly isolated from patients with normal hearts. ${ }^{14}$ Subsequent studies of this antiserum on tissue sections have been carried out by indirect immunofluorescence. ${ }^{16}$ After absorption with normal human serum, normal heart extracts and degraded fibrils from patients with primary and secondary amyloidosis, this antiserum reacted specifically with extramuscular amyloid deposits of tissue sections from cardiac ventricle infiltrated with senile amyloid. The antiserum did not react with normal hearts or with any tissue known to contain protein AA (secondary amyloidosis) or protein of the $\mathrm{AL}_{\lambda}$ type (primary or myeloma-associated amyloidosis). In addition, this antiserum failed to react with thyroid tissue known to contain amyloid associated with 
medullary carcinoma (MCT) or with amyloidcontaining pancreatic islets of Langerhans from elderly diabetic patients. Subsequent studies have shown that this antiserum fails to react with amyloid deposits associated with Congophilic angiopathy and amyloid of Alzheimer's plaques. ${ }^{17}$ The specificity of this antiserum for $\mathrm{ASc}_{\mathrm{I}}$ was confirmed by studies which showed that its reaction with tissues containing $\mathrm{ASc}_{\mathrm{I}}$ could not be blocked by a variety of purified amyloid proteins, but could be blocked completely by a low concentration $(0.1 \mathrm{mg} / \mathrm{ml})$ of purified $\mathrm{ASc}_{\mathrm{r}}{ }^{16}$ The existence of a unique protein in senile cardiac amyloidosis has also been reported by Gorevic et al. ${ }^{18}$

EVIDENCE FOR TWO TYPES OF SENILE AMYLOID OF THE HEART

Evidence for two distinct types of age-dependent cardiac amyloid is based on morphological, biochemical, and immunological studies. The more common type, isolated atrial amyloid (IAA), has recently been described ${ }^{13}$ and usually appears as very thin deposits occurring along the sarcolemma of atrial muscle cells. Small intracellular deposits are frequently present in such cells. The most pronounced deposits are usually seen in the auricles just beneath the endocardium, and very small vessels are commonly involved. Large homogeneous deposits are not present. The second type, generalised senile cardiac amyloid (SCA), described above, usually occurs as large homogeneous deposits between atrial and ventricular muscle bundles. Small and mediumsized arterial walls are often markedly thickened with amyloid. The degree of cardiac involvement varies but is generally widespread, only occasionally involving vessels alone. Unlike amyloid of the IAA type, SCA is often associated with small deposits in extracardiac tissues, especially the lung. ${ }^{13}$ Both types of cardiac amyloid show characteristic fibrillar electron microscopic appearance. 141718 However, only IAA is present as small deposits within muscle cells, often in association with muscular degeneration. Although both types of age dependent cardiac amyloid are congophilic, IAA differs from SCA and most other forms of amyloid in lacking the amino acid tryptophane. ${ }^{13}$

Immunological studies carried out by immunodiffusion $^{13}$ and immunofluorescence ${ }^{17}$ techniques indicate that IAA does not contain the small molecular weight protein ASc $\mathrm{c}_{\mathrm{r}}$ which is present in SCA. The latter protein has been demonstrated in small pulmonary deposits of patients with SCA (Cornwell GG III and Westermark P, unpublished observations).

\section{SUMMAR Y}

It appears that at least two separate forms of cardiac amyloid are associated with the aging process. One type (IAA) appears to be limited to the atria and appears at an earlier age. Although both types may coexist in the same heart tissue, the data suggest that they are pathogenically unrelated. The use of anti$\mathrm{ASc}_{\mathrm{I}}$ antiserum has provided the first opportunity to compare the biochemical nature of one form of age-dependent amyloid (SCA) with other wellknown types of age-dependent and age-independent amyloids. The failure of this antiserum to identify pancreatic amyloid deposits in elderly diabetics or cerebral amyloid deposits in patients with Alzheimer's disease indicates that amyloid deposits relating to the aging process may differ in their biochemical composition on the basis of organ localisation. This finding would be in contrast to that observed in generalised primary and secondary amyloidosis, in which the amyloid fibrils from different organs from the same individual are identical in their chemical composition.

The Table summarises some of the differences between senile amyloids of the heart and other forms of cardiac amyloidosis.

Comparison of senile amyloids of the heart with other forms of cardiac amyloidosis

\begin{tabular}{|c|c|c|c|}
\hline & $\begin{array}{l}\text { Senile } \\
\text { IAA }\end{array}$ & $\begin{array}{l}\text { Senile } \\
\text { SCA }\end{array}$ & Primary or secondary \\
\hline Age & Unknown & $\begin{array}{l}\text { Prevalence increases with } \\
\text { each decade above age } 60\end{array}$ & No correlation \\
\hline Cardiac location & $\begin{array}{l}\text { Atria only; interstitium } \\
\text { and small vessels; occasionally } \\
\text { intramuscular }\end{array}$ & $\begin{array}{l}\text { Atria and ventricles; } \\
\text { interstitium and small to medium } \\
\text { sized vessels }\end{array}$ & Interstitium and vessels \\
\hline Extracardiac involvement & None & $\begin{array}{l}\text { Usually localised to heart, } \\
\text { with focal involvement of } \\
\text { other tissues (especially lung) } \\
\text { when diffuse ventricular } \\
\text { involvement is present }\end{array}$ & $\begin{array}{l}\text { Significant involvement of many } \\
\text { other organs }\end{array}$ \\
\hline $\begin{array}{l}\text { Cardiomegaly } \\
\text { Cardiac failure }\end{array}$ & $\begin{array}{l}\text { None } \\
\text { None }\end{array}$ & $\begin{array}{l}\text { Uncommon } \\
\text { Uncommon }\end{array}$ & $\begin{array}{l}\text { Common in primary type } \\
\text { Moderately common in } \\
\text { primary type }\end{array}$ \\
\hline $\begin{array}{l}\text { Fibrils } \\
\text { Specific fibril proteins }\end{array}$ & $\begin{array}{l}\text { 'Insoluble' in water } \\
\text { Unknown }\end{array}$ & $\begin{array}{l}\text { Almost insoluble in water } \\
\text { ASc }_{\mathbf{I}}\end{array}$ & 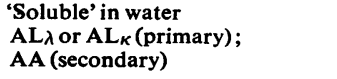 \\
\hline
\end{tabular}




\section{Amyloidosis of the pancreatic islets}

Amyloidosis of the islets of Langerhans was first described in the very beginning of this century and is still a puzzling problem. For a long time it was known as hyalinisation of the islets, and the amyloid nature of the deposited material was not accepted until the reactions with Congo red were shown, ${ }^{19}$ and Lacy ${ }^{20}$ demonstrated the fine fibrillar ultrastructure of the material. Since that time, the alteration has commonly been considered a form of senile amyloidosis.

Islet amyloidosis is a very common finding in elderly persons, and the frequency of affected islets increases with age. In fact, it is difficult to find persons of more than 70 years without at least one islet which contains amyloid. However, it is uncommon to find extensive islet amyloidosis in nondiabetic patients. The correlation of islet amyloidosis with maturity onset diabetes mellitus is well known. The percentage of affected islets and the degree of amyloidosis in such islets are much more pronounced in such patients than in non-diabetic persons. More than $50 \%$ of the islets in the tail and body of the pancreas are generally involved, ${ }^{21}$ whereas, for unknown reasons, the head of the pancreas is relatively spared. In juvenile diabetes mellitus, islet amyloid is very rarely, if ever, present. Islet amyloid is also seen in some diabetic animals, especially in cats $^{22}$ and apes. ${ }^{23}$

The amyloid is deposited extracellularly between the basement membranes of the epithelial cells and the vessels and is strictly limited to the islets. When the amount of amyloid increases, the endocrine cells degenerate and partially disappear. Typically, the $\beta$-cells are much more affected than the other endocrine cells. ${ }^{24}$ Ultrastructurally, the amyloid is composed of rigid, non-branching fibrils of about $100 \AA$ in thickness. In many areas, the fibrils are not easily detected, and the structure is more homogeneous. In most areas, the fibrils are randomly orientated, but in proximity to the endocrine cells parallel fibrils tend to form bundles. These are often seen to penetrate the membrane of the $\beta$-cells and to run into pockets of these cells exclusively. ${ }^{25}$ This relationship between amyloid fibrils and $\beta$-cells closely resembles that seen between amyloid fibrils and postulated fibril-forming cells in experimental amyloidosis $^{26}$ and has therefore been taken as evidence that the $\beta$-cell is responsible for the formation of amyloid fibrils in the islets of Langerhans. ${ }^{25}$

The islet amyloid demonstrates unique properties during homogenisation and isolation of fibrils. Instead of being broken up into individual fibrils, 15 most of the islet amyloid remains as large con- glomerates of fibrils. These conglomerates are largely insoluble in water and most solvents, and therefore no detailed chemical analysis of the proteins has been possible. ${ }^{27}$ Ultrastructurally, these conglomerates differ from the usual amyloid fibril morphology in that they contain very thin, small, wavy fibrils.

Insulin can easily be converted to fibrils which resemble amyloid fibrils, have affinity for Congo red, and exhibit green birefringence in polarised light. ${ }^{28} 29$ By using immunofluorescence techniques, some authors have reported that antibodies to insulin bind to islet amyloid in situ. ${ }^{30}$ We have performed the same experiment with both immunofluorescent and immunoperoxidase techniques but have not been able to obtain positive reactions. When treating purified islet amyloid with diluted sodium hydroxide, a procedure which converts fibrillar insulin to the native form, very small quantities of insulin can sometimes be extracted. ${ }^{29}$ However, this finding is inconstant, suggesting that fibrillar insulin does not represent a major component of islet amyloid. The connecting peptide (C-peptide) of proinsulin has also been proposed as the substratum for islet amyloid. ${ }^{31}$ However, this possibility appears unlikely since certain amino acids such as tyrosine ${ }^{29}$ and cystine (Westermark $P$, unpublished observations), which are not present in the C-peptide, seem to occur in islet amyloid.

Amyloid also occurs in some polypeptide hormone-producing tumours, especially those making insulin, calcitonin, and growth hormone. ${ }^{32}$ It is likely that the amyloid of the islets of Langerhans and the amyloid of the insulin-producing tumours are chemically identical. It is also probable that the amyloids of different amyloid-producing tumours share pathogenic similarities. The finding that a major fibril protein of the amyloid associated with medullary carcinoma of the thyroid is probably procalcitonin $^{33}$ may thus have implications for amyloid of the pancreatic islets. It seems very likely that islet amyloid contains a polymer of preproinsulin or a portion thereof, although it does not appear to contain intact insulin or C-peptide.

The antigenic properties of islet amyloid have been studied by immunodiffusion and immunofluorescent techniques. This form of amyloid does not react with antisera against protein AA, several different proteins of immunoglobulin origin, or the so-called void volume material (Vo) of amyloid. Antisera to $\mathrm{ASc}_{\mathrm{I}}$ and to the fibril subunit protein of the amyloid of medullary carcinoma of the thyroid, protein $\mathrm{AE}_{\mathrm{t}}$, also fail to react with islet amyloid. ${ }^{16}$ Thus the amyloid fibrils of the islets of Langerhans are immunologically different from other amyloid fibrils. On the other hand, the water- 
soluble P-component (protein AP) seems to be present in the amyloid of the islets, as in almost all other amyloids irrespective of type. ${ }^{34}$

The cause of islet amyloid and its influence on islet function are important unanswered questions. The islet amyloid has been mentioned as a possible cause of diabetes, since the substance might form a barrier between the $\beta$-cells and the capillaries. However, in many cases of maturity onset diabetes, the amount of amyloid is insufficient to account for a significant influence on the total islet cell mass. ${ }^{21} \mathrm{On}$ the other hand, despite rather small amounts of amyloid in pancreatic islets, severe cell membrane injuries are present in most $\beta$-cells ${ }^{25}$ with the result that there is a substantial reduction of the normal $\beta$-cell mass in this condition. ${ }^{21}$

We believe that islet amyloid does not cause diabetes but rather results from it. It is highly probable that maturity onset diabetes reflects $\beta$-cell dysfunction, but it is possible only to speculate about the nature of this dysfunction. It is well known that the islets in this disease have a partial inability to secrete synthesised insulin, an abnormality that may lead to stagnation of synthesised products (preproinsulin?) with subsequent polymerisation into amyloid fibrils. Partial degradation of such precursors probably occurs in a manner that has been postulated for other amyloids. 3536

\section{SUMMAR Y}

Islet amyloidosis is commonly found in elderly persons, but the degree of islet involvement is most extensive in patients with maturity onset diabetes mellitus. Morphological, biochemical, and immunological studies indicate that this form of amyloid has certain unique properties. Although its chemical structure is unknown, there is strong evidence that the fibrils are produced by the $\beta$-cells and may represent polymerisation products of a portion of preproinsulin synthesised by these cells. Islet amyloid does not appear to cause diabetes but probably results from dysfunction of the $\beta$-cells.

\section{Cerebrovascular amyloidosis}

In senile dementia, especially when associated with Aizheimer's disease, the occurrence of senile plaques in the cortex of the brain is a typical finding. The mature plaque has a unique morphology with a peripheral zone which contains neuronal processes and glia cells while the central core is free of cells. It has long been known that this core has staining properties of amyloid, 37 and its electron microscopic appearance is also typical of amyloid. ${ }^{38}$ The nature of the amyloid material is unknown and has been a subject of speculation. ${ }^{39}$ Histochemically, it has been compared to the 'apudamyloid' (amyloid of endocrine origin), since it has a low content of aromatic amino acids. ${ }^{40}$ The formation of amyloid is probably a secondary phenomenon, since primitive plaques do not contain any detectable amyloid. ${ }^{41}$

The neurofibrillary tangles, which occur intracellularly in neurons of Alzheimer's disease and, to some degree, in senile dementia, also show staining properties of amyloid. ${ }^{39}$ The tangles often, but not always, occur simultaneously with senile plaques. In spite of the similarity in staining properties with Congo red, the tangles have a morphological appearance which resembles microtubules and is quite different from the fibrils of the plaques. ${ }^{42}$ In fact it has recently been shown that antiserum to neurotubular antigens cross-reacts with the neurofibrillar tangles. ${ }^{43}$

The occurrence of amyloid deposits in vessels of the brain and the meninges (Congophilic angiopathy) in elderly persons is also a well-known phenomenon. The amyloid infiltration is located predominantly in the media of affected vessels. Such Congophilic angiopathy is seen almost uniformly in Alzheimer's disease and in senile dementia of the Alzheimer type. ${ }^{44}$ There is also a distribution correlation between angiopathy and senile plaques but not between angiopathy and the neurofibrillary tangles. ${ }^{44}$ Some investigators have found a correlation between the Congophilic angiopathy and amyloidosis of the cardiovascular system, ${ }^{45}$ but this observation has been denied by others (Cameron R, Brun A, personal communication). It seems clear, however, that the senile cardiac amyloid, which to some degree affects vessels outside the heart, is a disease different from the cerebrovascular amyloid since protein $\mathrm{ASc}_{\mathrm{I}}$ is not present in the latter. ${ }^{17}$ Whether the fibrils of the senile plaques and of the Congophilic angiopathy are chemically identical is unknown. It has been proposed that the amyloid of the senile plaques has a local origin, while the amyloid of the Congophilic angiopathy is derived from serum proteins. ${ }^{39}$

SUMMARY

Amyloid is usually found in cortical plaques associated with senile dementia and Alzheimor's disease. Congophilic angiopathy of the brain and meninges is also commonly present in patients with these disorders. The chemical nature and pathogenesis of these forms of amyloid are unknown, but it appears likely that their association with dementia is a secondary, rather than a primary, plicnomenon.

\section{Conclusion}

Senile amyloidosis includes a protean group of 
diseases which, while sharing some features common to all forms of amyloidosis, appear to be unique with respect to tissue localisation, ultrastructural appearance, extraction characteristics, and protein components. To date, only generalised senile cardiac amyloid (SCA) has yielded a specific protein comparable to $\mathrm{AL}_{\lambda}$ or $\mathrm{AL}_{\kappa}$ in primary or myeloma/ macroglobulin associated amyloid, AA in secondary amyloid, or $\mathrm{AE}_{\mathrm{t}}$ in amyloid associated with medullary carcinoma of the thyroid. Although there is speculation that an insulin-related protein is a major component of pancreatic islet amyloid, conclusive evidence is lacking. It appears likely that age-related amyloid causes direct clinical effects in only a small percentage of patients, but the true clinical significance of these forms of amyloid will not be known until biochemical methods of detecting them ante mortem are found.

We are grateful to Mrs Vibeke Goodall for expert technical assistance and to Ms Christine DeMasi for preparation of the manuscript.

This study was supported by grants from the Norwegian Rheumatism Council, the Norwegian Hydro Company, the Swedish Medical Council (project 102), and the Research Fund of the Swedish Association against Rheumatic Diseases.

\section{References}

${ }^{1}$ Lee HY, Kaufmann W. Cardiac amyloidosis in the aged. Arch Path 1957;64:494-500.

2 Mulligan RM. Amyloidosis of the heart. Arch Path 1958; 65:615-30.

${ }^{3}$ Buerger L, Braunstein H. Senile cardiac amyloidosis. Am J Med 1960;28:357-67.

- Eliot RS, McGee HJ, Blount SG Jr. Cardiac amyloidosis. Circulation $1961 ; 23: 613-22$.

${ }^{5}$ Schwartz P, Kurucz J. Amyloid deposits in the hearts of aged persons. J Am Geriatrics Soc 1965;13:718-22.

- Pomerance A. Senile cardiac amyloidosis. Brit Heart J 1965;27:711-18.

7 Pomerance A. The pathology of senile cardiac amyloidosis. J Path Bact 1966;91:357-67.

${ }^{8}$ Wright JR, Calkins E, Breen WJ, Stolte G, Schultz RT. Relationship of amyloid to aging. Review of the literature and systematic study of 83 patients derived from a general hospital population. Medicine $1969 ; 48: 39-60$.

- Schwartz P. Cardiovascular amyloidosis in the aged. Geriatrics 1969;24:81-97.

${ }^{10}$ Wright JR, Calkins E. Amyloid in the aged heart: frequency and clinical significance. J Am Geriatrics Soc 1975;23:97-103.

${ }^{11}$ Hodkinson HM, Pomerance A. The clinical significance of senile cardiac amyloidosis: a prospective clinicopathological study. Quart J Med 1977;46:381-87.

12 Cooper JH. An evaluation of current methods for the diagnostic histochemistry of amyloid. J Clin Pathol 1969;22:410-3.

13 Westermark P, Johansson B, Natvig JB. Senile cardiac amyloidosis: the existence of two different amyloid substances in the aging heart. Scand J Immunol 1979;
10:303-8.

14 Westermark P, Natvig JB, Johansson B. Characterization of an amyloid fibril protein from senile cardiac amyloid. J Exp Med 1977;146:631-6.

15 Pras M, Schubert M, Zucker-Franklin D, Rimon A, Franklin EC. The characterization of soluble amyloid prepared in water. J Clin Invest 1968;47:924-33.

${ }^{16}$ Cornwell GG, III, Natvig JB, Westermark P, Husby G. Senile cardiac amyloid: demonstration of a unique fibril protein in tissue sections. J Immunol 1978;120:1385-8.

17 Westermark P, Cornwell GG, III, Johansson B, Natvig JB. Senile cardiac amyloidosis. In Glenner GG, Costa PP, Falcao de Freitas A, eds. Amyloid and Amyloidosis. Amsterdam: Excerpta Medica Foundation; 1980:217-25.

18 Gorevic PD, Cleveland AB, Wright JR, Zucker-Franklin D, Frangione B, Franklin EC. Ultrastructural studies and partial characterization of a low molecular weight component of senile cardiac amyloid fibrils. In Glenner GG, Costa PP, Falcao de Freitas A, eds. Amyloid and Amyloidosis. Amsterdam: Excerpta Medica Foundation; 1980:366-72.

19 Ehrlich JC, Ratner IM. Amyloidosis of the islets of Langerhans. A restudy of islet hyalin in diabetic and nondiabetic individuals. Am J Pathol 1961;38:49-59.

${ }^{20}$ Lacy PE. Pancreatic beta cell. In: Cameron MP, O'Connor $\mathrm{M}$, eds. Aetiology of Diabetes Mellitus and its Complications. Ciba Foundation Colloquia on Endocrinology. Boston: Little, Brown and Co.; 1964:75-88.

21 Westermark $P$, Wilander $E$. The influence of amyloid deposits on the islet volume in maturity onset diabetes mellitus. Diabetologia $1978 ; 15: 417-21$.

22 Johnson KH, Stevens JB. Light and electron microscopic studies of islet amyloid in diabetic cats. Diabetes 1973; 22:81-90.

${ }^{23}$ Howard CF, Jr. Insular amyloidosis and diabetes mellitus in Macaca nigra. Diabetes 1978;27:357-64.

${ }^{21}$ Westermark P, Grimelius L. The pancreatic islet cells in insular amyloidosis in human diabetic and non-diabetic adults. Acta Path Microbiol Scand A 1973;81:291-300.

25 Westermark P. Fine structure of islets of Langerhans in insular amyloidosis. Virch Arch Path Anat 1973;359: 1-18.

${ }^{26}$ Cohen AS. The constitution and genesis of amyloid. Int Rev Exp Pathol 1965;4:159-243.

27 Westermark P. Amyloid of human islets of Langerhans. I. Isolation and some characteristics. Acta Path Microbiol Scand C. $1975 ; 83: 439-46$.

28 Glenner GG, Eanes ED, Bladen HA, Linke RP, Termine JD. $\beta$-pleated sheet fibrils. A comparison of native amyloid with synthetic protein fibrils. $J$ Histochem Cytochem 1974;22:1141-58.

29 Westermark P. On the nature of the amyloid in human islets of Langerhans. Histochemistry 1974;38:27-33.

${ }^{30}$ Berns AW, Owens CT, Blumenthal HT. A histo- and immunopathologic study of the vessels and islets of Langerhans of the pancreas in diabetes mellitus. $J$ Geront 1964;19:179-89.

31 Pearse AGE, Ewen SW, Polak JM. The genesis of apudamyloid in endocrine polypeptide tumours: histochemical distinction from immunamyloid. Virch Arch Abt B 1972;10:93-107.

32 Westermark P, Grimelius L, Polak JM, Larsson L-I, van Noorden S, Wilander E, Pearse AGE. Amyloid in polypeptide hormone-producing tumors. Lab Invest 1977;37:212-5.

${ }^{33}$ Sletten K, Westermark P, Natvig JB. Characterization of amyloid fibril proteins from medullary carcinoma of the thyroid. J Exp Med 1976;143:993-8.

${ }^{34}$ Westermark P, Skinner M, Cohen AS. The P-component of amyloid of human islets of Langerhans. Scand $J$ 
Immunol 1975;4:95-7.

${ }^{35}$ Lavie G, Zucker-Franklin D, Franklin EC. Degradation of serum amyloid A protein by surface-associated enzymes of human blood monocytes. J Exp Med 1978;148:102031.

${ }^{36}$ Glenner GG, Ein D, Eanes ED, Bladen HA, Terry W, Page DL. Creation of "amyloid" fibrils from Bence Jones proteins in vitro. Science $1971 ; 174: 712-4$.

${ }^{37}$ Hechst B. Zur Histochemie und Histogenese der senilen Plaques. Arch Psychiatr 1929;88:126-48.

38 Terry RD. Electron microscopic studies of Alzheimer's disease and of experimental neurofibrillary tangles. In Bailey OT, Smith DE, eds. The Central Nervous System: Some Experimental Models of Neurological Diseases. Baltimore: The Williams and Wilkins Co.; 1968:213-24.

${ }^{30}$ Glenner GG. Current knowledge of amyloid deposits as applied to senile plaques and congophilic angiopathy. In Katzman R, Terry RD, eds. Alzheimer's Disease: Senile Dementia and Related Disorders. New York: Raven Press; $1978: 493-502$.

${ }^{40}$ Powers JM, Spicer SS. Histochemical similarity of senile plaque amyloid to apudamyloid. Virch Arch Path Anat 1977;376:107-15.

41 Wiśniewski H, Johnson AB, Raine CS, Kay WJ, Terry RD Senile plaques and cerebral amyloidosis in aged dogs. Lab Invest 1970;23:287-96.

42 Wiśniewski HM, Harash K, Narang HK, Terry RD. Neurofibrillary tangles of paired helical filaments. $J$ Neurol Sci 1976;27:173-81.
${ }^{43}$ Grunkde-Iqbal I, Johnson AB, Wiśniewski HM, Terry RD, Iqbal $\mathbf{K}$. Evidence that Alzheimer neurofibrillary tangles originate from neurotubules. Lancet 1979;1: 578-80.

44 von Braunmühl A. Alterskrankungen des Zentralnervensystems. Senile Involution. Senile Demenz. Alzheimersche Krankheit. In Lubarsch O, Henke F, Rossle R, eds. Handbuch der speziellen patologischen Anatomie und Histologie. In: Scholz W, ed. 13:er Band: Nervensystem, Teil 1. Berlin: Springer-Verlag; 1957:337-59.

${ }^{45}$ Schwartz P. New patho-anatomic observations on amyloidosis in the aged. Fluorescence microscopic investigations. In Mandema E, Ruinen L, Scholten JH, Cohen AS, eds. Amyloidosis. Amsterdam: Excerpta Medica Foundation; 1968:400-17.

Requests for reprints to: Dr GG Cornwell III, Section of Hematology and Oncology, Dartmouth Medical School, Hanover, NH 03755, USA.

\section{Note added in proof}

Partial amino acid sequence studies have recently shown that amyloid fibril protein $\mathrm{ASc}_{\mathrm{r}}$ is homologous to a portion of human prealbumin (Sletten $\mathrm{K}$, Westermark P, Natvig JB. Senile cardiac amyloid is related to prealbumin. Scand J Immunol in press). 